\title{
Volatile Organic Compounds and Dominant Bacterial Community during Aerobic Composting of Vegetable Waste and Cow Manure Co-complexing
}

\author{
Haoli Qu, ${ }^{\mathrm{a}}$ Jie Cao, ${ }^{\mathrm{a}}$ Pengjun Wang, ${ }^{\mathrm{a}}$ Ruirong Li, ${ }^{\mathrm{a}}$ Zicheng Qi, ${ }^{\mathrm{b}}$ Jingjing Fu, \\ Yongsheng Chen, ${ }^{\mathrm{a}, *}$ and Mingjiang Chen ${ }^{\mathrm{a}, *}$
}

\begin{abstract}
Vegetable waste was aerobically composed using a trough-type system, and the resulting emitted volatile organic compounds were investigated. In addition, the succession pattern of microorganisms was analyzed. Aerobic fermentation was conducted using a tomato stalk-cow dung mix (a water content of $65 \%$ and a carbon-to-nitrogen ratio of $25: 1$ ). The emitted volatile organic compounds comprised of 58 kinds of compounds, including 2 sulfur-containing compounds, 3 alcohols, 3 esters, 3 aldehydes, 3 ketones, 6 halogenated hydrocarbons, 18 aromatic hydrocarbons, 17 alkanes, and 3 alkenes. The primary volatile organic compounds produced were methyl sulfide, ethyl acetate, ethanol, and acetaldehyde. Clustering and principal coordinate analysis suggested that the community succession changed throughout the composting process in the odorproducing habitat. High-throughput sequencing revealed that the bacterial community was comprised of Firmicutes, Chloroflexi, Proteobacteria, and Actinobacteria, whereas the dominant flora included Ascomycota, Basidiomycota, and Mucoromycota. These findings could aid in the mitigation of volatile organic compounds and odors during vegetable waste composting as well as contribute to the development of deodorizing bacteria.
\end{abstract}

DOI: 10.15376/biores.17.1.1338-1353

Keywords: Vegetable waste; Stalk; Volatile organic compound (VOCs); Aerobic composting; Odor pollutants; $16 S$ rRNA sequencing

Contact information: a: Ministry of Agriculture, Nanjing Research Institute for Agricultural Mechanization, Nanjing 210014 People's Republic of China; b: Shandong Academy of Agricultural Machinery Sciences, Jinan 250100 People's Republic of China;

* Corresponding authors: cys003@sina.com; cmj_cn@163.com

\section{INTRODUCTION}

China is characterized by widespread vegetable planting, with large amounts of waste being generated during the production and processing of vegetables. Assuming that this waste accounts for $30 \%$ of the total vegetable yield, the total amount of vegetable waste amounts to more than 245 million tons (Liu et al. 2020). Vegetable waste has a high-water content, and disorderly stacking produces large amounts of volatile organic compounds (VOCs), which can cause environmental pollution (Scaglia et al. 2011).

During the humification of compost, a large amount of VOCs are produced. Owing to vigorous microbial activity and gradual increase in temperature during composting, some VOCs are produced and released (Shen et al. 2011). VOCs may arise from the raw materials themselves, or they may be generated as a result of incomplete decomposition of 
organic compounds (Sánchez-Monedero et al. 2019).

Different types of organic waste can produce a wide range of VOCs during the fermentation process, due to differences in fermentation materials, processes, and equipment. In addition, microorganisms play an important role in aerobic composting (Ma et al. 2021). The microbial community composition can change during composting, as so can the production of odors.

Currently, research into VOCs has primarily focused on their production during the aerobic composting of sludge (Ma et al. 2014), domestic waste (Zhang et al. 2012; Zhang et al. 2013), and livestock and poultry manure (Sánchez-Monedero et al. 2019; Liu et al. 2020). However, the composition of odor produced during the aerobic composting of agricultural waste (primarily from solanaceous vegetable waste) is not clear. Furthermore, few studies have investigated changes in the characteristics of the dominant microbial communities during this process.

In this study, an industrialized trough dumping process (uncovered) was used, with solanaceous vegetable waste used as the primary raw material; it was supplemented with cow dung to carry out a joint aerobic composting test. The emission characteristics of the VOCs produced at different fermentation stages were analyzed, with high-throughput sequencing to analyze changes in the dominant components of the microbial community. This study provides a theoretical basis for odor control and microbial regulation during the treatment of vegetable waste.

\section{EXPERIMENTAL}

\section{Feedstock and Inoculums}

Fresh vegetable stalk (tomato stalk) was collected from an experimental field in Shouguang, Shandong Province, China. It was cut to approximately $20 \mathrm{~mm}$ size with a grinder and then baled into $5 \mathrm{~kg}$ bundles. Fresh cow manure, taken from a cow farm in Shouguang, was used as a subsidiary feedstock. The parameters of the fermentation feedstock are listed in Table 1.

Table 1. Characteristics of the Raw Materials Used in the Experiments

\begin{tabular}{|c|c|c|c|c|c|c|c|}
\hline Item & $\begin{array}{c}\text { Carbon } \\
\text { Content } \\
(\%)\end{array}$ & $\begin{array}{c}\text { Nitrogen } \\
\text { Content } \\
(\%)\end{array}$ & $\begin{array}{c}\text { Phosphorus } \\
\text { Content (\%) }\end{array}$ & $\begin{array}{c}\text { Potassium } \\
\text { Content } \\
(\%)\end{array}$ & $\begin{array}{c}\text { Organic } \\
\text { Matter (\%) }\end{array}$ & $\begin{array}{c}\text { Moisture } \\
(\%)\end{array}$ & $\mathrm{pH}$ \\
\hline $\begin{array}{c}\text { Cow } \\
\text { manure } \\
\text { (CM) }\end{array}$ & 38.78 & 1.78 & 0.91 & 0.66 & 84.91 & 63.48 & 9.33 \\
\hline $\begin{array}{c}\text { Tomato } \\
\text { stalk (TS) }\end{array}$ & 16.82 & 1.5 & 2.61 & 1.22 & 79.24 & 55.08 & 7.36 \\
\hline
\end{tabular}

\section{Digester System}

A bed composting process was used in this study (as shown in Fig. 1). Parallel tanks were used, which were $5 \mathrm{~m}$ wide, $2 \mathrm{~m}$ high, and $100 \mathrm{~m}$ long. The tank body intermittently stirred the stack body by turning and moving forward.

A fermentation bin (as shown in Fig. 1, part 5) was used as the experimental site. Because it is difficult to collect gas in a large-scale open fermentation system, an in-situ test device $(200 \mathrm{~L})$ was adopted for bed composting to collect gas. During the different 
fermentation periods, the sampler was placed at different sampling sites for sample collection.

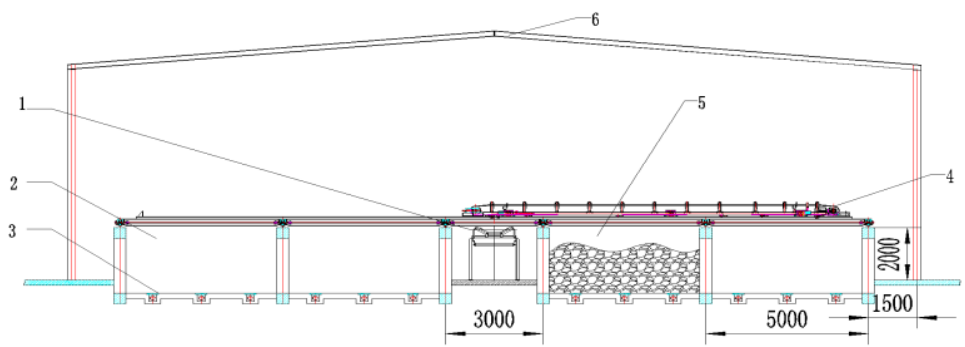

Fig. 1. Schematic diagram of the aerobic fermentation device: 1) belt conveyor unloading device; 2) fermentation bin; 3) aeration pipeline; 4) input and output device; 5) experimental bin; and 6) greenhouse above fermentation area (Note: the values in this figure are in millimeters)

\section{Experimental Design}

Vegetable stalks were crushed and removed pieces of plastic through raw material pretreatment; the lengths of stalks after the pretreatment were less than $20 \mathrm{~mm}$. The crushed tomato stalks were fed into the apparatus using a straw quantitative feeder. The cow dung was supplied using a dung water quantitative supply system, and the crushed straw material and cow dung were mixed. The carbon-to-nitrogen $(\mathrm{C} / \mathrm{N})$ ratio of the mixture was $25: 1$, and the moisture content of the composting pile was $65 \%$. Thermophilic inoculants were added to the total amount of the mixture, at a ratio of $1 \%$. The thickness of the fermented material reached 1.5 to $1.8 \mathrm{~m}$, and it was turned over every 1.5 to $3 \mathrm{~d}$. On days 0 (S1), 5 (S2), 10 (S3), 15 (S4), 20 (S5), 25 (S6), 30 (S7), 35 (S8), and 40 (S9), samples were collected and stored at $-80{ }^{\circ} \mathrm{C}$ until analysis; the temperature in the fermentation bin was recorded at the time of each sampling.

\section{Chemical Analysis}

All chemicals were obtained from Sinocem (Shanghai, China) or Fluka Chemical (Buchs, Switzerland). The oxygen production was tracked using an ultrasonic gas flow meter (BF-30008-160, Wuhan Sifang Company, Wuhan, China). The temperature was monitored using a multi-channel temperature recorder (JWB/33, ColliHigh, Beijing, China). The nitrate $\left(\mathrm{NH}_{3}\right)$ concentrations were measured using a detection tube (GASTEC, Kanagawa, Japan). The VOCs were analyzed via gas chromatography-mass spectroscopy (GC-MS; Agilent 7890A 5975C, Agilent, Santa Clara, CA).

\section{Microbial Community Analysis}

Deoxyribonucleic acid (DNA) extraction and purity testing were performed as described by Ma et al. (2018). The V4 to V5 region of the bacterial 16S ribosomal ribonucleic acid (rRNA) gene was amplified via polymerase chain reaction (PCR) at $95^{\circ} \mathrm{C}$ for $2 \mathrm{~min}$, followed by 25 cycles at $95{ }^{\circ} \mathrm{C}$ for $30 \mathrm{~s}, 55^{\circ} \mathrm{C}$ for $30 \mathrm{~s}, 72{ }^{\circ} \mathrm{C}$ for $30 \mathrm{~s}$, and subsequently a final extension step at $72{ }^{\circ} \mathrm{C}$ for $5 \mathrm{~min}$. The following primers were used: 515F 5'-barcode-GTGCCAGCMGCCGCGG-3' and 907R 5'-CCGTCAATTCMTTTRAGTTT-3'.

A library was constructed using the combined V4 region of the 16S rDNA district, based on Illumina MiSeq Technology. The amplicon library was paired-end sequenced (2 $\times 250$ ) on an Illumina MiSeq platform (Shanghai BIOZERON Co., Ltd.), according to standard protocols. 


\section{Statistical Analysis}

All experiments and analytical measurements were conducted in triplicate. The standard deviations and fitted curves were analyzed using Microsoft Excel 2013 (Redmond, WA) for Windows and Origin 9.1 (Northampton, MA) for Windows. All bacterial community structure analyses were performed using the Vegan package in $\mathrm{R}$ (Dixon 2015). The differences in the bacterial community structures were evaluated using principal coordinates analysis (PCoA) based on Bray-Curtis distances, using the relative abundances of operational taxonomic units (OTUs) without singletons as the input data.

\section{RESULTS AND DISCUSSION}

\section{Changes in Oxygen and Temperature during Aerobic Composting}

The temperature during vegetable composting is an important indicator of the degree of harmlessness in terms of VOCs. The high temperature period of aerobic composting can quickly eliminate pathogenic bacteria in the compost pile, which is the primary factor for ensuring the smooth progress of aerobic composting (Shen et al. 2016). In this study, the aerobic composting cycle for the vegetable waste was $40 \mathrm{~d}$. As shown in Fig. 2, during the composting of vegetable waste, the overall temperature first increased and then decreased. The high-temperature aerobic composting period lasted for more than $15 \mathrm{~d}$.

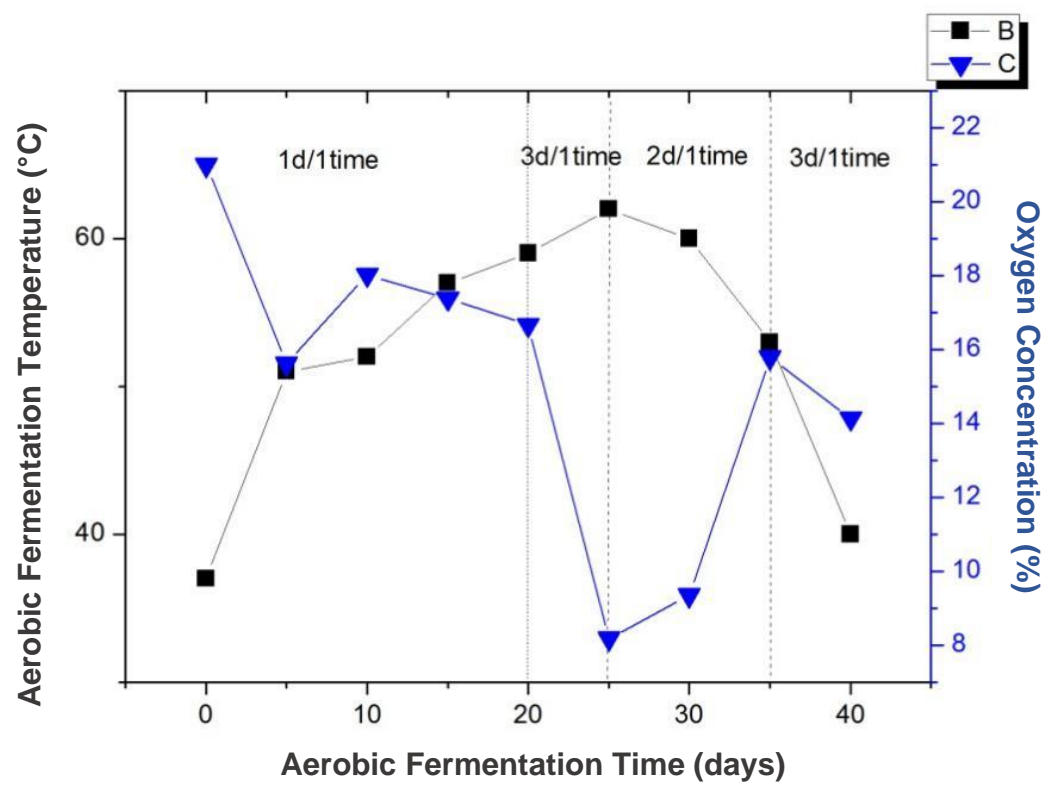

Fig. 2. Dynamic changes in temperature and oxygen during the vegetable waste aerobic composting process

On the $4^{\text {th }}$ day of aerobic composting, the temperature of the vegetable waste rose to greater than $50{ }^{\circ} \mathrm{C}$. The oxygen concentration showed alternating increasing and decreasing trends; it first declined and then increased (1 to $10 \mathrm{~d}$ ), and then again declined before increasing again ( 15 to $35 \mathrm{~d}$ ). In the 20 to $25 \mathrm{~d}$ stage, the composting temperature remained high, the maximum amount of oxygen was consumed, and the oxygen content in the composting reactor was the lowest. After day 25, the turning frequency increased (from 
$3 \mathrm{~d} /$ time to $2 \mathrm{~d} /$ time), as did the oxygen concentration. The high temperature period (greater than $55{ }^{\circ} \mathrm{C}$ ) during the aerobic composting of the vegetables exceeded $15 \mathrm{~d}$, which complied with the technical regulations for composting vegetable residues in agricultural clean production, according to DB standard 13/T 2327-2016 (2016), and the technical specifications for the sanitation treatment of livestock and poultry manure, according to GB/T standard 36195 (2018), thereby meeting the temperature requirements for decomposition.

\section{Analysis of Odor Components During the Aerobic Composting of Vegetable waste and Cow Manure Co-complexing}

Among the VOCs, aromatic hydrocarbons were the most numerous, followed by alkenes. A total of 58 VOCs were detected during the aerobic fermentation of vegetable stalks (as shown in Table 2), including 2 sulfur-containing compounds (methyl sulfide and carbon disulfide), 3 alcohols (ethanol, isopropanol, and n-butanol), 3 esters (methyl acetate, ethyl acetate, and propyl acetate), 3 aldehydes (acetaldehyde, butyraldehyde, and 2acrolein), 3 ketones (acetone, 2-butanone, and methylisobutylketone), 6 halogenated hydrocarbons (trichloromonofluoromethane, dichloromethane, chloroform, 1,2dichloroethane, carbon tetrachloride, and perchloroethylene), 18 aromatic hydrocarbons (toluene, chlorobenzene, ethylbenzene, $m$-xylene, $p$-xylene, styrene, $o$-xylene, 1,2,4trimethylbenzene, 1,4-dichlorobenzene, naphthalene, benzene, isopropyl benzene, propyl benzene, $m$-ethyl toluene, $o$-ethyl toluene, 1,2,3-trimethylbenzene,a-pinene, and limonene), 17 alkanes (decane, heptane, heptane, $n$-hexane, undecane, dodecane, cyclopentane, 2-methylpentane, 3-methyl pentane, methyl cyclopentane, 2,3dimethylpentane, 2,2,4-trimethylpentane, methyl cyclohexane, 2,3,4-trimethylpentane, 3methylheptane, octane, 2-methyl butane, and pentane), and 3 alkene compounds (1-butene, 2-methyl-1,3-butadiene, and trichloroethylene).

In addition to the 58 types of $\mathrm{VOC}_{\mathrm{S}}, \mathrm{NH}_{3}$ was also detected; however, hydrogen sulfide was not detected, even when the test was repeated two times.

Among the 58 VOCs detected, 7 exceeded the odor threshold; these were methyl sulfide, ethyl alcohol, $n$-butyl alcohol, ethylacetate, acetaldehyde, butyraldehyde, and $\alpha$ pinene. These 7 substances are the primary sources of gas flavor in the aerobic composting of vegetable waste. In addition, $\mathrm{NH}_{3}$ exceeded the olfactory threshold, whereas $\mathrm{H}_{2} \mathrm{~S}$ was not detected. The $\mathrm{NH}_{3}$ concentrations were higher than the olfactory threshold during all stages of aerobic composting. The odor threshold reference was determined based on previous studies (Wang et al. 2015; Zhang et al. 2019). The emission concentrations of the four volatile substances, viz., methyl sulfide, carbon disulfide, styrene, and $\mathrm{NH}_{3}$, exceeded the requirements of emission standards for odor pollutants, according to GB standard 14554 (2018). Therefore, methyl sulfide and $\mathrm{NH}_{3}$ were the main odorants during aerobic composting of vegetable waste and cow manure co-complexing. The methyl sulfide concentration decreased from $0.0007 \mathrm{mg} \cdot \mathrm{m}^{-3}$ at the start of aerobic composting to $0 \mathrm{mg} \cdot \mathrm{m}^{-}$

${ }^{3}$; it then gradually increased to $0.1926 \mathrm{mg} \cdot \mathrm{m}^{-3}$ after $20 \mathrm{~d}$, before gradually decreasing again. 
Table 2. Concentrations of the Volatile Compounds Emitted During the Aerobic Composting of Vegetables Waste

\begin{tabular}{|c|c|c|c|c|c|c|c|c|}
\hline \multirow{2}{*}{$\begin{array}{l}\text { Compound } \\
\text { Type }\end{array}$} & \multirow{2}{*}{ Component } & \multicolumn{6}{|c|}{ Time (d) } & \multirow{2}{*}{$\begin{array}{c}\text { Olfactory } \\
\text { Threshold } \\
\text { Value } \\
\left(\mathrm{mg} \cdot \mathrm{m}^{-3}\right)\end{array}$} \\
\hline & & $\mathrm{S} 1(1)$ & S3(10) & S5(20) & S6(25) & $S 7(30)$ & S8(35) & \\
\hline \multirow{2}{*}{$\begin{array}{c}\text { Sulfur } \\
\text { compounds }\end{array}$} & $\begin{array}{c}\text { Methyl } \\
\text { sulfide } \#\end{array}$ & 0.0007 & $\mathrm{~N}$ & N & 0.1926 & 0.0029 & $\mathrm{~N}$ & 0.003 \\
\hline & $\begin{array}{c}\text { Carbon } \\
\text { disulfide* }^{*}\end{array}$ & 0.0072 & 0.0130 & 0.0140 & 0.0530 & 0.0064 & 0.0048 & 0.17 \\
\hline \multirow{3}{*}{ Alcohols } & Ethyl alcohol\# & 1.1786 & 0.0064 & $\mathrm{~N}$ & $\mathrm{~N}$ & 0.1421 & 0.0903 & 0.1 \\
\hline & Isopropanol & 0.2334 & 0.0240 & 0.0211 & 0.1859 & 0.0150 & $\mathrm{~N}$ & 3.9 \\
\hline & $\begin{array}{c}n \text {-Butyl } \\
\text { alcohol\# }\end{array}$ & 0.0165 & $\mathrm{~N}$ & $\mathrm{~N}$ & 0.0570 & $\mathrm{~N}$ & $\mathrm{~N}$ & 0.066 \\
\hline \multirow{3}{*}{ Esters } & $\begin{array}{l}\text { Methyl } \\
\text { acetate }\end{array}$ & 0.8444 & 0.0111 & 0.0043 & $\mathrm{~N}$ & $\mathrm{~N}$ & $\mathrm{~N}$ & - \\
\hline & Ethyl acetate\# & 19.1061 & $\begin{array}{l}19.041 \\
9\end{array}$ & 11.8807 & 34.4323 & 1.6209 & 1.0724 & 0.84 \\
\hline & Propyl acetate & 0.0670 & 0.0943 & 0.0879 & 0.6046 & 0.0233 & $\mathrm{~N}$ & I \\
\hline \multirow{3}{*}{ Aldehydes } & $\begin{array}{c}\text { Acetaldehyde } \\
\#\end{array}$ & 0.0748 & 0.0230 & 0.0329 & $\mathrm{~N}$ & $\mathrm{~N}$ & $\mathrm{~N}$ & 0.018 \\
\hline & $\begin{array}{c}\text { Butyraldehyde } \\
\# \\
\end{array}$ & 0.0011 & N & $\mathrm{N}$ & $\mathrm{N}$ & 0.0006 & $\mathrm{~N}$ & 0.00085 \\
\hline & 2 - Acrolein & $\mathrm{N}$ & $\mathrm{N}$ & 0.0036 & $\mathrm{~N}$ & $\mathrm{~N}$ & $\mathrm{~N}$ & 1 \\
\hline \multirow{3}{*}{ Ketones } & Acetone & 0.1528 & 0.2479 & 0.3120 & 0.3803 & 0.0147 & 0.0085 & 7.2 \\
\hline & 2-Butanone & 0.0059 & $\mathrm{~N}$ & $\mathrm{~N}$ & 0.4362 & 0.0046 & 0.0036 & 2 \\
\hline & $\begin{array}{l}\text { Methylisobutyl } \\
\text { ketone }\end{array}$ & $\mathrm{N}$ & $\mathrm{N}$ & $N$ & 0.0087 & $\mathrm{~N}$ & $\mathrm{~N}$ & 0.11 \\
\hline \multirow{6}{*}{$\begin{array}{l}\text { Halogenated } \\
\text { hydrocarbons }\end{array}$} & $\begin{array}{c}\text { Trichloromono } \\
\text { Fluoromethan } \\
\text { e }\end{array}$ & $\mathrm{N}$ & $\mathrm{N}$ & $\mathrm{N}$ & $\mathrm{N}$ & $\mathrm{N}$ & 0.0007 & I \\
\hline & $\begin{array}{l}\text { Dichloro- } \\
\text { methane }\end{array}$ & 0.0137 & 0.0151 & 0.0175 & 0.0112 & 0.0036 & 0.0026 & l \\
\hline & Chloroform & 0.0038 & $\mathrm{~N}$ & $\mathrm{~N}$ & $\mathrm{~N}$ & 0.0194 & 0.0200 & I \\
\hline & $\begin{array}{l}\text { 1,2-Dichloro- } \\
\text { ethane }\end{array}$ & 0.0058 & $\mathrm{~N}$ & $\mathrm{~N}$ & 0.0069 & 0.0057 & 0.0052 & 6 \\
\hline & $\begin{array}{c}\text { Carbon } \\
\text { Tetrachloride }\end{array}$ & $\mathrm{N}$ & $\mathrm{N}$ & $\mathrm{N}$ & $\mathrm{N}$ & $\mathrm{N}$ & 0.0008 & 1721 \\
\hline & $\begin{array}{c}\text { Perchloro- } \\
\text { ethylene }\end{array}$ & 0.0005 & $\mathrm{~N}$ & $\mathrm{~N}$ & 0.0045 & 0.0004 & $\mathrm{~N}$ & l \\
\hline \multirow{8}{*}{$\begin{array}{c}\text { Aromatic } \\
\text { hydrocarbons }\end{array}$} & Toluene & 0.0520 & 0.0594 & 0.0630 & 0.0780 & 0.0321 & 0.0162 & 0.17 \\
\hline & $\begin{array}{c}\text { Chloro- } \\
\text { benzene }\end{array}$ & 0.0002 & $\mathrm{~N}$ & 0.0007 & 0.0009 & 0.0002 & $\mathrm{~N}$ & 1 \\
\hline & Ethylbenzene & 0.0081 & 0.0115 & 0.0115 & 0.0135 & 0.0065 & 0.0036 & 0.018 \\
\hline & $m$-Xylene & 0.0121 & 0.0162 & 0.0175 & 0.0172 & 0.0119 & 0.0070 & 0.091 \\
\hline & $p$-Xylene & 0.0054 & 0.0155 & 0.0077 & 0.0069 & 0.0059 & 0.0036 & 0.12 \\
\hline & Styrene* & 0.0102 & 0.0213 & 0.0211 & 0.0231 & 0.0034 & 0.0007 & 0.034 \\
\hline & o-Xylene & 0.0073 & 0.0117 & 0.0104 & 0.0097 & 0.0057 & 0.0027 & 0.28 \\
\hline & $\begin{array}{c}1,2,4- \\
\text { Trimethyl- } \\
\text { benzene }\end{array}$ & $\mathrm{N}$ & 0.0014 & 0.0014 & $N$ & $\mathrm{~N}$ & 0.0012 & 0.3 \\
\hline
\end{tabular}




\begin{tabular}{|c|c|c|c|c|c|c|c|c|}
\hline & $\begin{array}{l}\text { 1,4-Dichloro- } \\
\text { benzene }\end{array}$ & 0.0024 & 0.0063 & 0.0064 & 0.0037 & 0.0007 & $\mathrm{~N}$ & l \\
\hline & Naphthalene & 0.0047 & 0.0070 & 0.0077 & 0.0071 & 0.0020 & 0.0013 & 1.5 \\
\hline & Benzene & 0.0039 & 0.0082 & $\mathrm{~N}$ & 0.0072 & 0.0025 & 0.0020 & 9.4018 \\
\hline & $\begin{array}{l}\text { Isopropyl } \\
\text { benzene }\end{array}$ & 0.0003 & N & $\mathrm{N}$ & 0.0005 & 0.0002 & $\mathrm{~N}$ & 0.0429 \\
\hline & $\begin{array}{c}\text { Propyl } \\
\text { benzene }\end{array}$ & 0.0003 & $\mathrm{~N}$ & $\mathrm{~N}$ & 0.0004 & 0.0003 & 0.0002 & l \\
\hline & $\begin{array}{l}m \text {-Ethyl } \\
\text { toluene }\end{array}$ & 0.0006 & 0.0008 & $\mathrm{~N}$ & $\mathrm{~N}$ & 0.0008 & 0.0007 & l \\
\hline & $\begin{array}{c}\text { o-Ethyl } \\
\text { toluene }\end{array}$ & $N$ & 0.0022 & $\mathrm{~N}$ & $\mathrm{~N}$ & $\mathrm{~N}$ & $\mathrm{~N}$ & 1 \\
\hline & $\begin{array}{c}1,2,3- \\
\text { Trimethyl- } \\
\text { benzene }\end{array}$ & $\mathrm{N}$ & $\mathrm{N}$ & $\mathrm{N}$ & 0.0005 & $\mathrm{~N}$ & N & l \\
\hline & a-Pinene\# & 0.0021 & 0.0021 & 0.0023 & 0.0032 & 0.0010 & 0.0004 & 0.001 \\
\hline & Limonene & 0.0104 & 0.0107 & 0.0107 & 0.0117 & 0.0071 & 0.0067 & 0.016 \\
\hline \multirow{17}{*}{ Alkanes } & Decane & 0.0250 & 0.1460 & 0.1076 & 0.0860 & 0.0035 & $\mathrm{~N}$ & 1 \\
\hline & Heptane & 0.0039 & 0.0081 & 0.0072 & 0.0076 & 0.0013 & $\mathrm{~N}$ & 1 \\
\hline & $n$-hexane & 0.0084 & 0.0533 & 0.0101 & $\mathrm{~N}$ & 0.0052 & 0.0048 & 1 \\
\hline & Undecane & 0.0011 & $\mathrm{~N}$ & $\mathrm{~N}$ & 0.0032 & $\mathrm{~N}$ & $\mathrm{~N}$ & 1 \\
\hline & Dodecane & 0.0169 & 0.0959 & 0.0971 & 0.0704 & $\mathrm{~N}$ & $\mathrm{~N}$ & 1 \\
\hline & Cyclopentane & 0.0087 & $\mathrm{~N}$ & 0.0683 & 0.0594 & 0.0030 & 0.0019 & 1 \\
\hline & $\begin{array}{l}\text { 2-Methyl- } \\
\text { pentane }\end{array}$ & $\mathrm{N}$ & N & $\mathrm{N}$ & $\mathrm{N}$ & $\mathrm{N}$ & 0.0018 & l \\
\hline & $\begin{array}{l}\text { 3-Methyl } \\
\text { pentane }\end{array}$ & 0.0036 & $N$ & $\mathrm{~N}$ & 0.0075 & 0.0015 & $\mathrm{~N}$ & I \\
\hline & $\begin{array}{c}\text { Methyl } \\
\text { cyclopentane }\end{array}$ & $\mathrm{N}$ & $\mathrm{N}$ & $\mathrm{N}$ & $\mathrm{N}$ & 0.0012 & 0.0011 & I \\
\hline & $\begin{array}{c}2,3- \\
\text { Dimethylpenta } \\
\text { ne }\end{array}$ & $\mathrm{N}$ & $\mathrm{N}$ & $\mathrm{N}$ & N & 0.0009 & $\mathrm{~N}$ & I \\
\hline & $\begin{array}{c}2,2,4- \\
\text { Trimethyl- } \\
\text { pentane }\end{array}$ & $\mathrm{N}$ & $\mathrm{N}$ & $\mathrm{N}$ & $\mathrm{N}$ & $\mathrm{N}$ & $\mathrm{N}$ & I \\
\hline & $\begin{array}{c}\text { Methyl } \\
\text { cyclohexane }\end{array}$ & 0.0009 & $\mathrm{~N}$ & $\mathrm{~N}$ & 0.0013 & 0.0005 & 0.0003 & I \\
\hline & $\begin{array}{c}2,3,4- \\
\text { Trimethyl- } \\
\text { pentane }\end{array}$ & $\mathrm{N}$ & $\mathrm{N}$ & $\mathrm{N}$ & $\mathrm{N}$ & 0.0004 & $\mathrm{~N}$ & I \\
\hline & $\begin{array}{l}\text { 3-Methyl- } \\
\text { heptane }\end{array}$ & 0.0092 & 0.0235 & 0.0215 & 0.0185 & 0.0010 & $\mathrm{~N}$ & I \\
\hline & Octane & 0.0143 & 0.0603 & 0.0427 & 0.0350 & 0.0022 & $\mathrm{~N}$ & I \\
\hline & $\begin{array}{l}\text { 2-Methyl } \\
\text { butane }\end{array}$ & 0.0421 & 0.0220 & 0.0199 & 0.0432 & 0.0123 & 0.0105 & I \\
\hline & Pentane & 0.0370 & 0.0330 & 0.0384 & 0.0870 & 0.0137 & 0.0098 & 1 \\
\hline \multirow{4}{*}{ Alkenes } & 1-Butene & $\mathrm{N}$ & $\mathrm{N}$ & $\mathrm{N}$ & 0.5707 & 0.0065 & 0.0075 & 1 \\
\hline & $\begin{array}{c}\text { 2-Methyl-1,3- } \\
\text { butadiene }\end{array}$ & 0.0095 & $\mathrm{~N}$ & $\mathrm{~N}$ & $\mathrm{~N}$ & 0.0020 & 0.0010 & I \\
\hline & $\begin{array}{c}\text { Trichloroethyl } \\
\text { ene }\end{array}$ & $\mathrm{N}$ & $\mathrm{N}$ & $\mathrm{N}$ & $\mathrm{N}$ & $\mathrm{N}$ & 0.0006 & I \\
\hline & $\mathrm{NH}_{3}{ }^{*} \#$ & 57 & 76 & 10 & 72 & 78 & 26 & 0.027 \\
\hline
\end{tabular}


Methyl sulfide had a higher detection rate after $25 \mathrm{~d}$. During this period, the oxygen content in the material decreases, and there will be some anaerobic zones around the compost block, which is more likely to produce methyl sulfide and may also be related to the reduced frequency of flipping (Parkinson et al. 2004; Zhang et al. 2018). The turning operation can provide sufficient oxygen inside the compost, thereby reducing the odor. However, while increasing the number of stacks, a large amount of gas overflows, and may increase the detected concentration.

Most of the primary odor contributors during the aerobic composting of raw materials included sulfide substances. This was consistent with the findings of studies analyzing the VOCs in vegetable (Zhang et al. 2019), pig manure (Shen et al. 2019), cow manure (Liu et al. 2020), and domestic waste composts (Zhang et al. 2013).

Other types of emissions, for example, $\alpha$-pinene and limonene, were also detected during the entire composting process, consistent with a study analyzing the VOCs produced during fruit aerobic composting (Wu and Wang 2015). Organic waste can give off considerable amounts of terpenes during early disposal under aerobic conditions (Wang and $\mathrm{Wu} 2008$ ).

In this study, large amounts of benzene compounds were detected, which may be related to the compounding of some cow dung within the composted material; aromatic compounds in cow dung compost have been shown to greatly contribute to odor concentration (Liu et al. 2020). Although many types of alkanes were detected, their emission concentrations fluctuated between 0 to $0.2 \mathrm{mg} \cdot \mathrm{m}^{-3}$ during the entire composting process; thus, this type of substance only made a small contribution to the odor concentration in the compost.

The vegetable waste used in this study was comprised of solanaceous stalks, with the VOC types detected during composting being more complicated than in the composting of leafy vegetables (Zhang et al. 2019).

In addition to different composting substrates, VOCs can also be affected by the fermentation parameters, including ventilation, temperature, water content, and the C-to-N ratio (Hubbe et al. 2010; Jiang et al. 2011; Maulini-Duran et al. 2014; Chinakwe et al. 2019). In this study, only the VOCs emitted during aerobic composting of mixed wastes of vegetables and cow dung were monitored, and further monitoring and analysis of VOCs emissions under different process conditions are needed in the future.

\section{Bacterial Community Succession}

Bacterial and fungal community succession during the vegetable waste composting process

High-throughput sequencing technology revealed structural changes in the bacterial community (at the phylum level), as shown in Fig. 3. Firmicutes, Chloroflexi, Proteobacteria, and Actinobacteria were the dominant flora, and the sum of their relative abundance comprised $80 \%$ of the entire bacterial flora. In the initial stage of composting, that is, S1 to S3 (between $1 \mathrm{~d}$ to $15 \mathrm{~d}$ ), the abundance of Firmicutes increased, before decreasing during S4 to S5 (between $15 \mathrm{~d}$ to $25 \mathrm{~d}$ ). The abundance of Chloroflexi gradually increased during S1 to S5 (1 d to $25 \mathrm{~d}$ ), then gradually decreased after $25 \mathrm{~d}$, and thereafter, remained at a low abundance.

As shown in Fig. 4, most of the dominant genera are unknown, followed by Bacillus, Longispora, and Hydrogenispora. Bacillus is mainly related to cellulose degradation. From the beginning to the end of composting, the abundance of Bacillus increased.

The structural changes in the fungal community (at the phylum level) are shown in

Fig. 5; Ascomycota, Basidiomycota, and Mucoromycota were the dominant flora. 
Ascomycota occupied a dominant position throughout the composting; this phylum is widespread and can degrade lignocellulose (Wang et al. 2018; Xia et al. 2021). Basidiomycota can also degrade lignocellulose, with higher abundances achieving greater organic matter degradation ( $\mathrm{Hu}$ et al. 2019). These two types of fungi are thought to play an important role in the decomposition of vegetable waste.

The dominant genera of fungi during 1-10 days of composting were Mycothermus, Thermomyces, Acaulium, Aspergillus, Acremonium, and Scopulariopsis, as shown in Fig. 6. During this period, the temperature rises, most microorganisms start being dormant or they die under high temperature, and thermophilic microorganisms (such as Thermomyces) rapidly multiply and become the dominant microorganisms. During the stage of composting (10-20 d), the Mycothermus fungi replace the thermophilic fungi to become the dominant flora. Mycothermus is the dominant flora at the composting stage, which may decompose the remaining macromolecular substances and provides energy for the later stage of composting.

$\mathrm{NH}_{3}$ is an important odor-causing factor in the composting process. We further analyzed the correlation between the concentration of $\mathrm{NH}_{3}$ emitted and the abundance of the microbial community at the genus level. There were 13 genera of bacteria that are significantly related to the production of $\mathrm{NH}_{3}$ during the composting process.

Desulfitibacter, Paenibacillus, and Haloplasma are related to the ammonia concentration $(\mathrm{P}<0.05)$. There were four genera of fungi related to the production of $\mathrm{NH}_{3}$ during composting, including Meyerozyma, Alternaria, Hapsidospora, and Aspergillus $(\mathrm{P}<0.01)$.

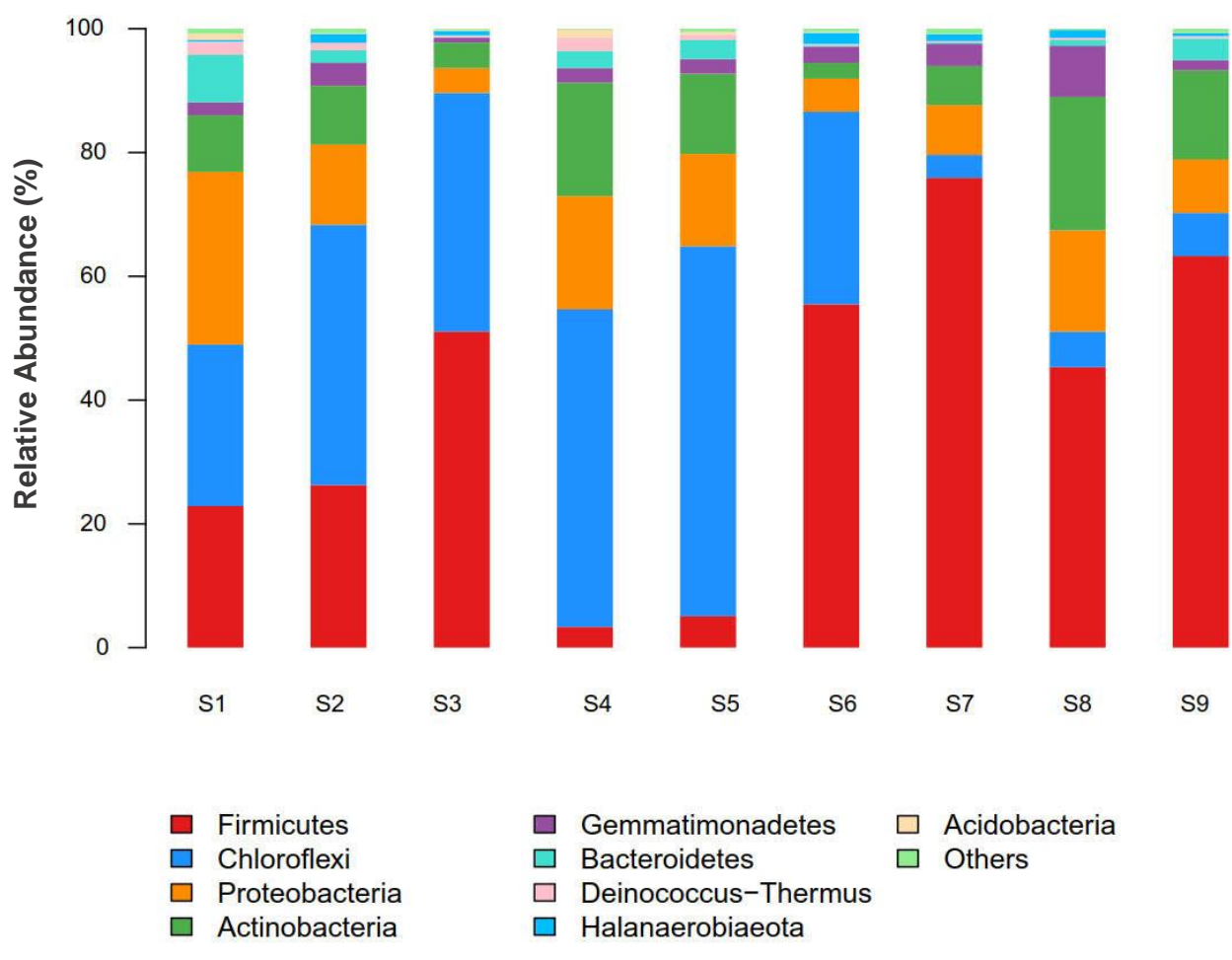

Fig. 3. Bacterial community composition at the phylum level 


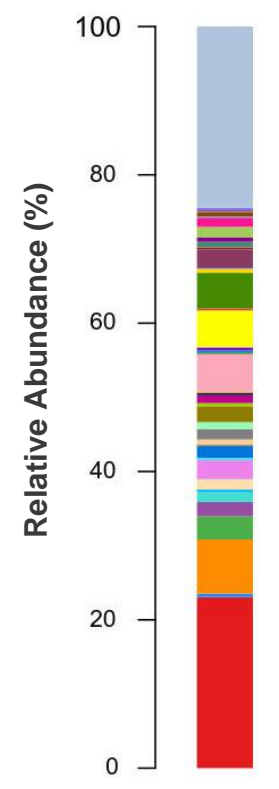

S1

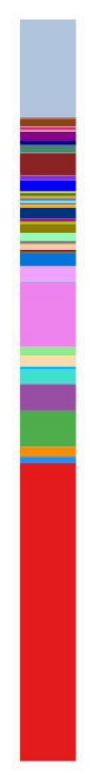

S2

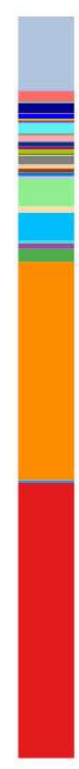

S3

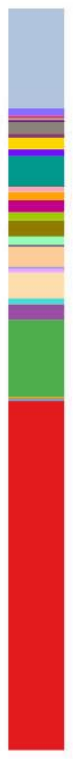

S4

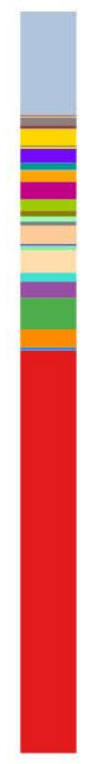

S5

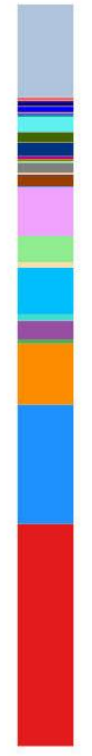

S6

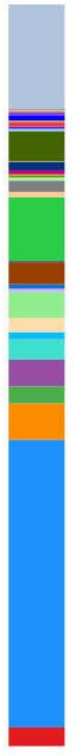

S7

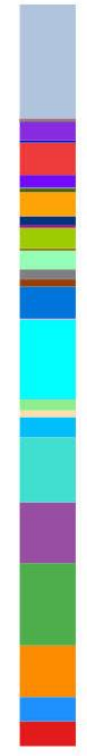

S8

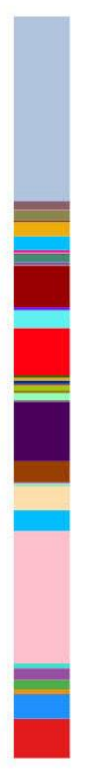

S9
$\square$ SBR1031_norank
$\square$ Bacillus
$\square$ Limnochordaceae_norank
$\square$ Longispora
$\square$ S0134 terrestrial group_norank
$\square$ Methylococcaceae_uncultured
$\square$ Bhargavaea
$\square$ Hydrogenispora
$\square$ Actinomarinales_norank
$\square$ Bacillales_norank
$\square$ Solibacillus
$\square$ Cohnella
$\square$ Ureibacillus
$\square$ Thermobacillus
$\square$ Caldicoprobacter
- Oceanobacillus
$\square$ Aneurinibacillus
$\square$ Others

Fig. 4. Bacterial community composition at the genus level

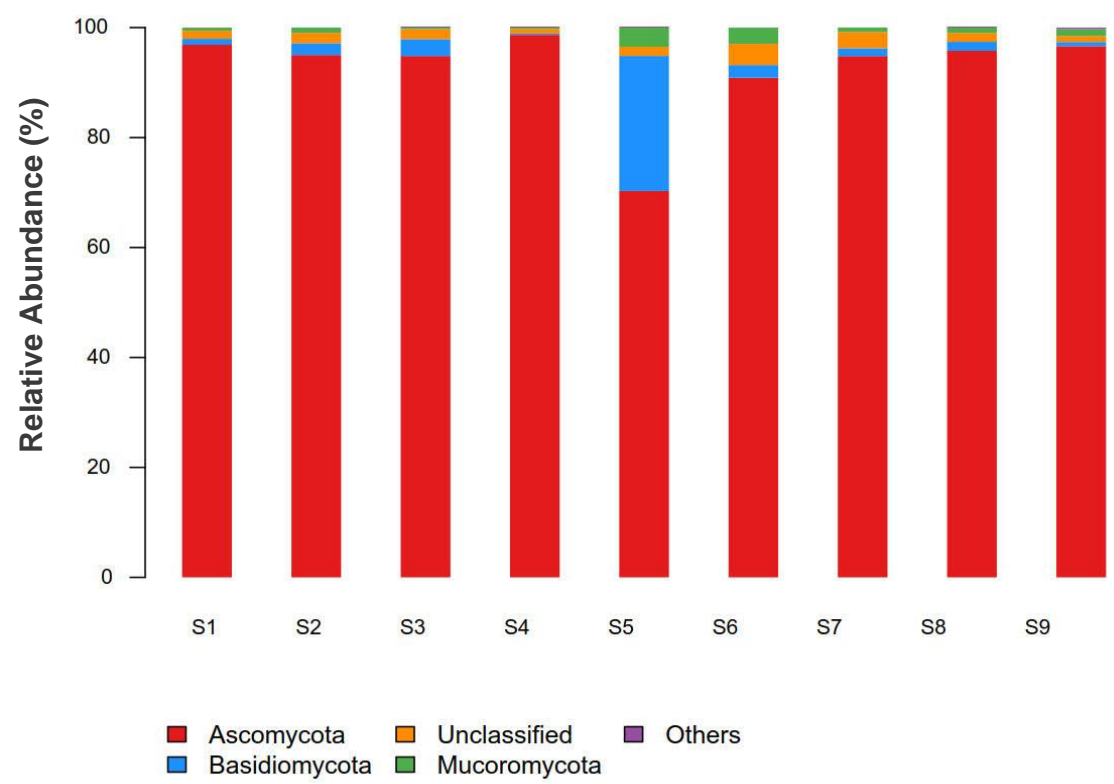

Fig. 5. Fungi community composition at the phylum level 


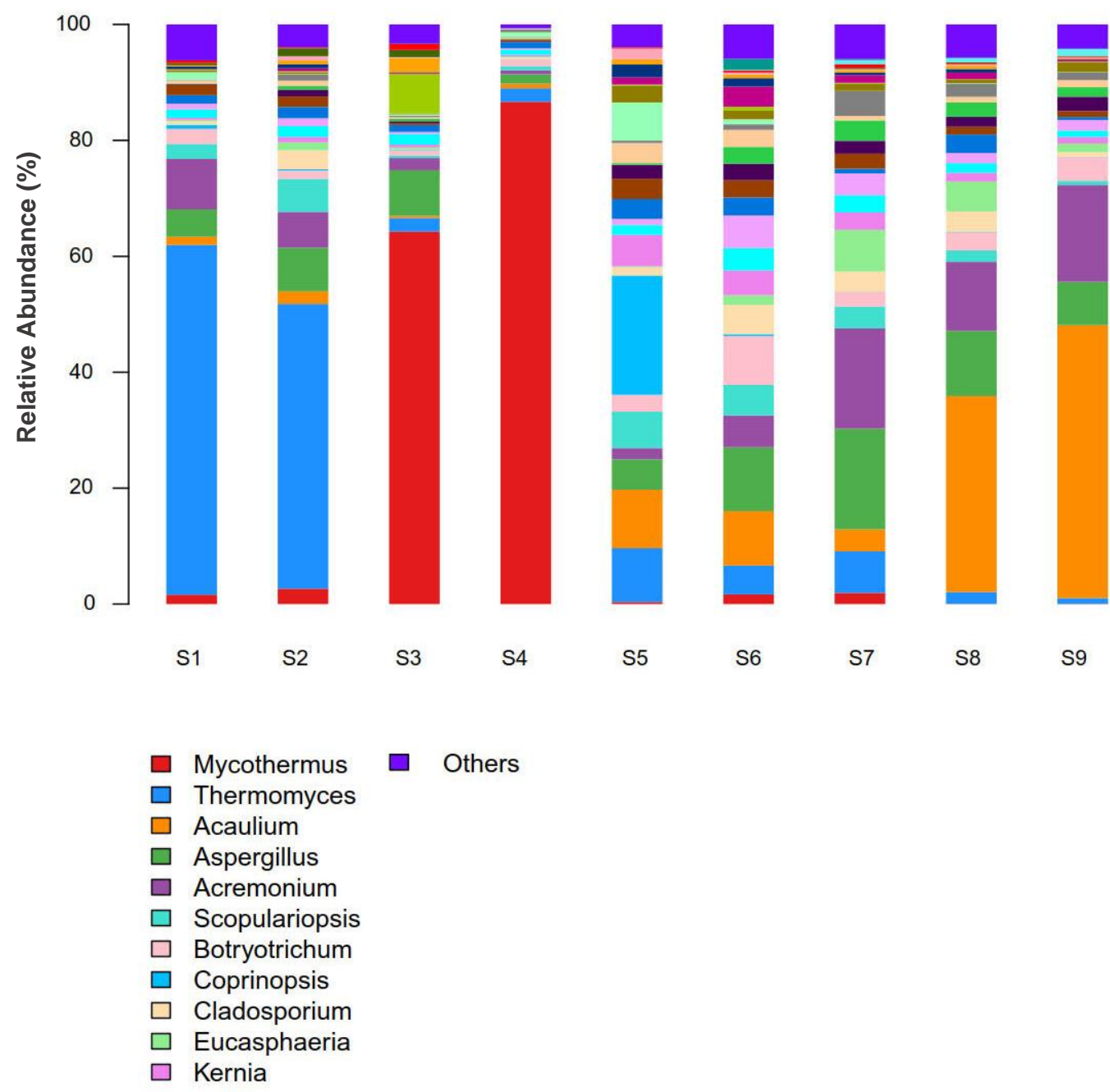

Fig. 6. Fungi community composition at the genus level

Principal coordinates analysis (PCoA) (Jiang et al. 2013) is a visualization method to study the similarity or differences in data, which indicate differences between individuals or groups. Figure 7 shows the PCoA of the bacterial communities, revealing that the clusters contained nine samples of aerobic composting. The periods S1 through S5, that is, during the initial stage of composting, were spaced closer together, suggesting that the bacterial community was relatively stable during the first $25 \mathrm{~d}$ of composting. The changes observed in the bacterial community diversity at the S6 through S9 stage may have been caused by the change in the composting community as a result of the decrease in oxygen concentration in the reactor.

Figure 8 shows the PCoA of the fungal communities. Nine compost samples from different periods were clustered into three groups ( S1 through S2, S3 through S4, and S5 through S9). This indicated that the fungal community of the vegetable waste compost underwent three successive stages. Samples S1 and S2 were closer together, which indicated that the fungal communities in the first $5 \mathrm{~d}$ of composting were similar. The samples after the temperature rise, that is, S3 and S4, were further apart, which indicated that the fungal community underwent major changes during the evolution from the low temperature period to the high temperature period. The fungal community ( 55 through $\mathrm{S} 11$ ) 
gathered together after $20 \mathrm{~d}$ in the late composting stage, which indicated that the fungal community at this stage gradually tended toward stability. Compared with the previous two stages, it changed considerably.

Although the relationship between the succession of microorganisms during the composting process has been revealed, that between the succession of colonies and the occurrence of odor during the composting process needs to be further studied.

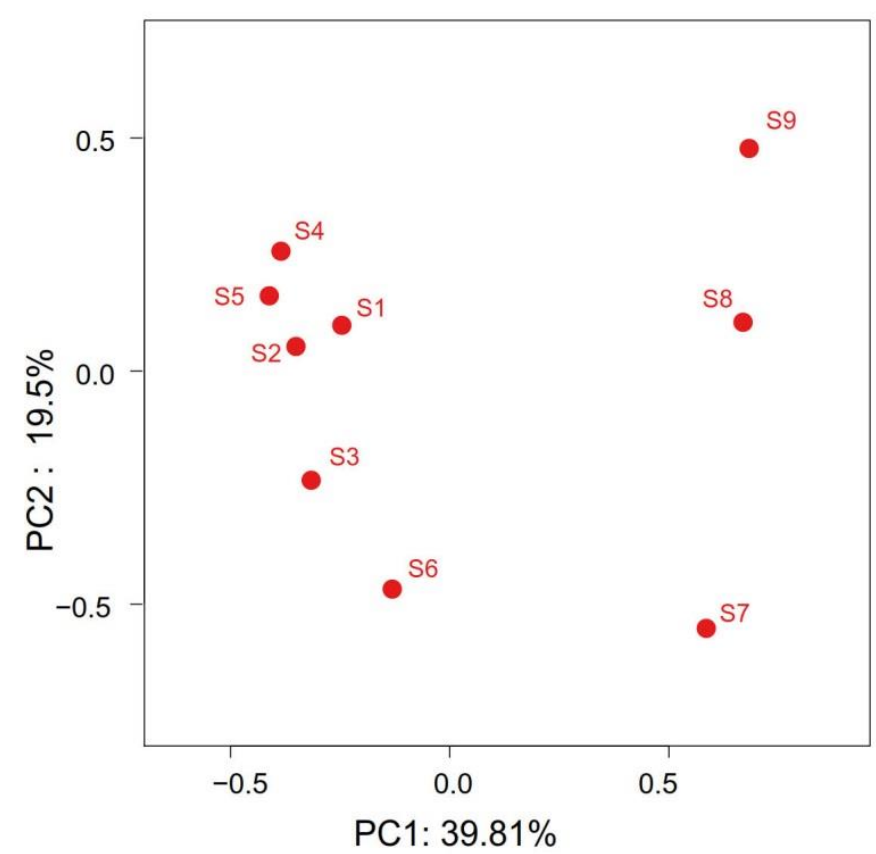

Fig. 7. Principal coordinates analysis (PCoA) of the bacterial communities

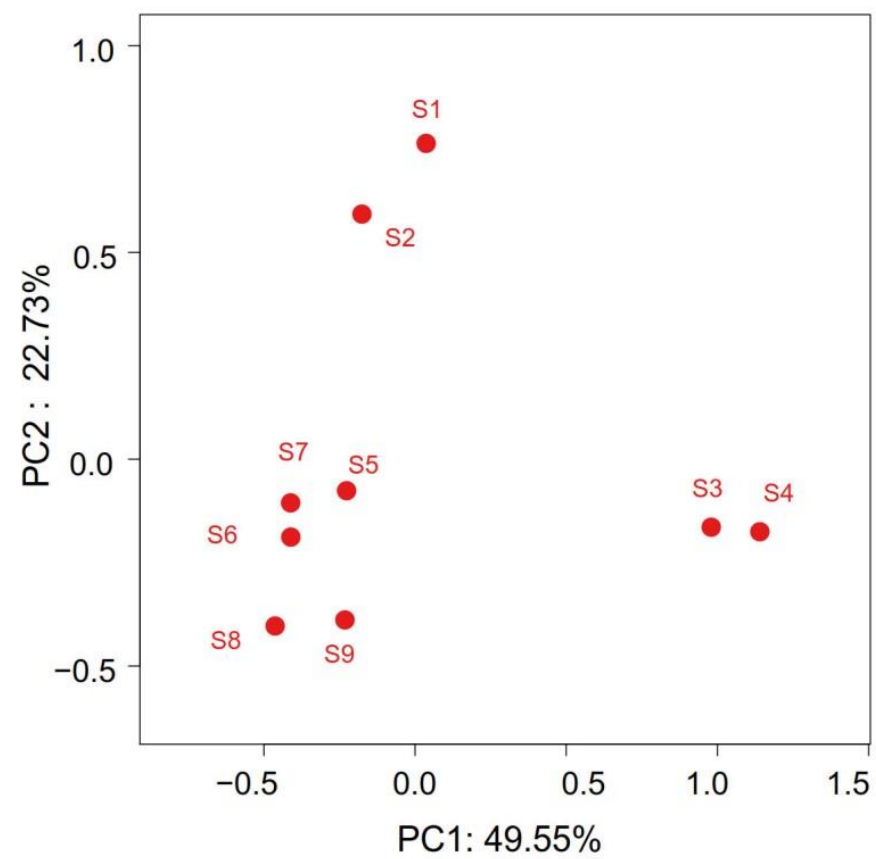

Fig. 8. Principal coordinates analysis (PCoA) of fungal communities 


\section{CONCLUSIONS}

This study provides information about the odor-producing substances that can be used as an indicator for monitoring the generation of these compounds during the composting of agricultural waste in the future. It provides a theoretical basis for odor control and microbial regulation during the treatment of vegetable waste.

1. A total of 58 volatile organic compounds (VOCs) were detected during the aerobic composting of vegetable waste (as the primary raw material). These VOCs comprised a complex mixture of 2 sulfur-containing compounds, 3 alcohols, 3 esters, 3 aldehydes, 3 ketones, 6 halogenated hydrocarbons, 18 aromatic hydrocarbons, 17 alkanes, and 3 alkenes.

2. Methyl sulfide, ethyl alcohol, n-butyl alcohol, ethylacetate, acetaldehyde, butyraldehyde, styrene, and $\alpha$-pinene were the primary sources of gas flavor in the aerobic composting process. Methyl sulfide and $\mathrm{NH}_{3}$ were the main odorant during aerobic composting of vegetable waste and cow manure co-complexing.

3. The bacterial community structure from the aerobic composting of vegetable waste consisted of Firmicutes, Chloroflexi, Proteobacteria, and Actinobacteria, according to high-throughput sequencing (MiSeq). The dominant flora were Ascomycota, Basidiomycota, and Mucoromycota.

\section{ACKNOWLEDGMENTS}

The authors are grateful for the support provided by the Fundamental Research Funds for Central Non-profit Scientific Institutions (Grant No. s202004-03 and No. s202004), the Agricultural Science and Technology Innovation Program: The CAASNIAM-SJ-201901, and the Shandong Province Major Science and Technology Innovation Project (Grant No. 2019JZZY020619). The authors are grateful for the support provided by the Key Research and Development Program of Hebei Province (Grant No. 20327313D).

\section{REFERENCES CITED}

Chinakwe, E. C., Ibekwe, V. I., Ofoh, M. C., Nwogwugwu, N. U., Adeleye, S. A., Chinakwe, P. O., Nwachukwu, I. N., and Ihejirika, C. E. (2019). "Effect of temperature changes on the bacterial and fungal succession patterns during composting of some organic wastes in greenhouse," Journal of Advances in Microbiology 15(1), 1-10. DOI: 10.9734/jamb/2019/v15i130075

DB 13/T 2327 (2016). "Technical regulations for composting vegetable residues in cleaner agricultural production," Hebei Provincial Bureau of Quality and Technical Supervision, Hebei, China.

GB 14554 2018. (2018). "Emission standards for odor pollutants," Standardization Administration of China, Beijing, China.

GB/T 36195 2018. (2018). "Technical specification for sanitation treatment of livestock and poultry manure," Standardization Administration, Beijing, China. 
Hu, T., Wang, X., Zhen, L., Gu, J., Zhang, K., Wang, Q., Ma, J., Peng, H., Lei, L., and Zhao, W. (2019). "Effects of inoculating with lignocellulose-degrading consortium on cellulose-degrading genes and fungal community during co-composting of spent mushroom substrate with swine manure," Bioresource Technology 291, 1-36. DOI: 10.1016/j.biortech.2019.121876

Hubbe, M. A., Nazhad, M., and Sanchez, C. (2010). "Composting as a way to convert cellulosic biomass and organic waste into high-value soil amendments: A review," BioResources 5(4), 2808-2854. DOI: 10.15376/biores.5.4.2808-2854

Jiang, T., Schuchardt, F., Li, G., Guo, R., and Zhao, Y. (2011). "Effect of C/N ratio, aeration rate and moisture content on ammonia and greenhouse gas emission during the composting," Journal of Environmental Sciences 23(10), 1754-1760. DOI: 10.1016/S1001-0742(10)60591-8

Jiang, X., Peng, X., Deng, G., Sheng, H., Yu, W., Zhou, H., and Tam, F. (2013). "Illumina sequencing of $16 \mathrm{~S}$ rRNA tag revealed spatial variations of bacterial communities in a mangrove wetland," Microb Ecol 66(1), 96-104. DOI: 10.1007/s00248-013-0238-8

Liu, J., Yao, X., Sheng, D., Shuchen, S., Yang, W., Wei, R., Chen, J., Ding, X., and Tian, X. (2020). "Analysis and prospects for resource utilization of vegetable waste in China," Journal of Agricultural Resources and Environment 5(37), 636-644. DOI: 10.13254/j.jare.2019.0267

Liu, W., Shen, Y., Meng, H., Zhang, X., Zhao, L., Ding, J., Zhou, H., and Wang, L. (2020). "Emission characteristics of volatile matter and identification of odor substances during aerobic fermentation of cattle manure," Transactions of the Chinese Society of Agricultural Engineering 36(22), 222-230. DOI:

10.11975/j.issn.1002-6819.2020.22.025

Liu, W., Wang, L., Shen, Y., Zhang, X., Meng, H., Fan, S., and Zhang, D. (2020). "Effects of carbon to nitrogen ratio on maturity and odor emission in aerobic fermentation of vegetable waste," Environmental Engineering 38(6), 233-239. DOI: 10.13205/j.hjgc.202006038

Ma, C., Zhao, Z., Zhao, J., Zhang, H., Wei, M., and Ye, C. (2014). “Contamination risk of volatile organic compounds during sludge composting," Ecology and Environmental Sciences 23(6), 1022-1026

Ma, S., Fang, C., Sun, X., Han, L., He, X., and Huang, G. (2018). “Bacterial community succession during pig manure and wheat straw aerobic composting covered with a semi-permeable membrane under slight positive pressure," Bioresource Technology 259, 221-227. DOI: 10.1016/j.biortech.2018.03.054

Ma, S., Xiong, J., Wu, X., Liu, H., Han, L., and Huang, G. (2021). "Effects of the functional membrane covering on the gas emissions and bacterial community during aerobic composting," Bioresource Technology 340, 1-8. DOI: 10.1016/j.biortech.2021.125660

Maulini-Duran, C., Puyuelo, B., Artola, A., Font, X., Sánchez, A., and Gea, T. (2014). "VOC emissions from the composting of the organic fraction of municipal solid waste using standard and advanced aeration strategies," Journal of Chemical Technology and Biotechnology 4(89), 579-586. DOI: 10.1002/jctb.4160

Parkinson, R., Gibbs, P., Burchett, S., and Misselbrook, T. (2004). "Effect of turning regime and seasonal weather conditions on nitrogen and phosphorus losses during aerobic composting of cattle manure," Bioresource Technology 91(2), 171-178. DOI: 10.1016/S0960-8524(03)00174-3 
Sánchez-Monedero, M. A., Sánchez-García, M., Alburquerque, J. A., and Cayuela, M. L. (2019). "Biochar reduces volatile organic compounds generated during chicken manure composting," Bioresource Technology 288, 1-5. DOI: 10.1016/j.biortech.2019.121584

Scaglia, B., Orzi, V., Artola, A., Font, X., Davoli, E., Sanchez, A., and Adani, F. (2011). "Odours and volatile organic compounds emitted from municipal solid waste at different stage of decomposition and relationship with biological stability," Bioresource Technology 102(7), 4638-4645. DOI: 10.1016/j.biortech.2011.01.016

Shen, Y. J., Gao, D., Chen, T. B., Di, Z. G. D., and Liu, H. T. (2011). "Production and emission of volatile organic compounds during composting," China Water \& Wastewater 27(11), 101-108. DOI: 10.19853/j.zgjsps.1000-4602.2011.11.035.

Shen, Y., Zhang, D., Zhao, L., Meng, H., and Cheng, H. (2016). "Component analysis of volatile organic compounds and determination of key odor in pig manure aerobic fermentation process," Transactions of the Chinese Society of Agricultural Engineering 32(4), 205-210. DOI: 10.11975/j.issn.1002-6819.2016.04.029

Shen, Y., Zhang, P., Meng, H., Zhao, L., Cheng, H., Zhou, H., and Zhang, X. (2019). "Effects of ventilation modes on control of main odor substances in pig manure composting," Transactions of the Chinese Society of Agricultural Engineering 35(7), 203-209. DOI: 10.11975/j.issn.1002-6819.2019.07.025

Wang, B., Zhai, Z., Jing, G., Han, M., and Lu, F. (2015). "Determination of the odor threshold of 40 kinds of typical malodorous substances," Journal of Safety and Environment 15(6), 348-351. DOI: 10.13637/j.issn.1009-6094.2015.06.072

Wang, K., Yin, X., Mao, H., Chu, C., and Tian, Y. (2018). "Changes in structure and function of fungal community in cow manure composting," Bioresource Technology 255, 123-130. DOI: 10.1016/j.biortech.2018.01.064

Wang, X., and Wu, T. (2008). "Release of isoprene and monoterpenes during the aerobic decomposition of orange wastes from laboratory incubation experiments," Environmental Science \& Technology 42(9), 3265-3270. DOI: 10.1021/es702999j

$\mathrm{Wu}, \mathrm{T}$., and Wang, X. (2015). "Emission of oxygenated volatile organic compounds (OVOCs) during the aerobic decomposition of orange wastes," Journal of Environmental Sciences 33, 69-77. DOI: 10.1016/j.jes.2015.01.006

Xia, J., Wang, Y., Dong, C., Liu, H.-N., Tang, H., and Shang, T. (2021). "Effects of different microbial inoculants on the physical and chemical properties and dominant microbial communities in the composting process of garden waste," Journal of Henan Agricultural University 55(3), 551-560. DOI: 10.16445 /j.cnki.10002340.20210414.003

Zhang, H., Zou, K., Yang, J., Li, G., Yang, X., and Zhang, F. (2012). "Analysis of odor pollutants in kitchen waste composting," Environmental Science 33(8), 2563-2568. DOI: $10.13227 / j . h j k x .2012 .08 .032$

Zhang, H. Y., Li, G. X., and Yang, Q. Y. (2013). "Odor pollutants analyzing during municipal solid waste (MSW)composting," Transactions of the Chinese Society of Agricultural Engineering 29(9), 192-199. DOI: 10.3969/j.issn.10026819.2013.09.025

Zhang, H., Chen, F., Jie, S., and Pi, J. S. (2018). "Research progress on odor emission in composting of livestock and poultry manure and biological deodorization," Acta Ecologiae Animalis Domastici 39(1), 84-89. DOI: CNKI:SUN:JCST.0.2018-01-021 
Zhang, X., Meng, H., Liu, W., Shen, Y., Zhao, L., Zhang, P., Wang, J., Zhou, H., Cheng, H., and Song, L. (2019). "Emission characteristics of volatile organic compounds during vegetable residues and livestock manure combined aerobic fermentation," Transactions of the Chinese Society of Agricultural Engineering 35(22), 193-199. DOI: $10.11975 / \mathrm{j}$. issn.1002-6819.2019.22.023

Article submitted: November 10, 2021; Peer review completed: November 30, 2021;

Revised version received and accepted: December 26, 2021; Published: January 7, 2022. DOI: 10.15376/biores.17.1.1338-1353 